\title{
Genetic diversity and population structure of three commercial indigenous Aloe species in selected ASALs of Kenya
}

Asenath Adienge ${ }^{1 *}$, Gabriel Muturi ${ }^{1}$, Stanley Nadir ${ }^{1}$, John Gicheru' ${ }^{1}$, Johnson Kinyua ${ }^{2}$ and Jane Ngaira ${ }^{2}$

*Correspondence: adiengeasenath@gmail.com

CrossMark

\& Click for updates

${ }^{1}$ Kenya Forestry Research Institute. P.O Box 20412-00200, Nairobi, Kenya.

2Jomo Kenyatta University of Agriculture and Technology. P.O. Box 62,000 - 00200, Nairobi, Kenya.

\begin{abstract}
Aloe species are common in arid and semi-arid lands (ASALs) of Kenya and are of economic importance especially for bitter gum production. However, the species is under ecological threat due to unsustainable harvesting from the wild. The objective of this study was to evaluate genetic diversity and population structure of three commercially exploited indigenous Aloe species; A. secundiflora, A. turkanensis and A. scabrifolia. The study was carried out in fifteen populations of Aloe species in their wild habitat where their geographic distribution was surveyed and populations delineated. Within each population, 30 trees were sampled at a distance of $100 \mathrm{~m}$ apart where leaf tissues were collected for DNA isolation and analysis using modified Cetyl trimethyl ammonium bromide (CTAB) method. Randomly amplified polymorphic DNA (RAPDs) and Inter-simple sequence repeats (ISSR) markers were used to determine the genetic diversity and population structure. Ten RAPD and seven ISSR discriminative primers with the highest value of genetic diversity were selected to genotype three indigenous Aloe species. The genetic similarity was performed using Popgene 1.3.1; hierarchical UPGMA cluster analysis and principal coordinate analysis were performed using Genalex 6.5. To map genetic structure and gene pools, both Structure and Structure Harvester statistical packages were used. From the results, $A$. secundiflora species was the most distributed in the surveyed ASALs. There was high genetic variation among and within the populations. The combined use of ISSR and RAPD revealed high variations among the populations as compared to when either of them used singly. Genetic variation was highest within secundiflora species and least within turkanensis species. Maralal secundiflora population had the highest genetic variation. The study exhibited a population genetic structure with three major clusters which corresponded to the three Aloe species with minimal reproductive crossing among them. It is therefore, recommended to undertake biophysical studies to determine the advantages of A.secundiflora that has over the other species. In addition, Maralal sec population should be conserved ex-situ because of its high genetic diversity while both ISSR and RAPD markers should be prioritized in Aloe genetic studies as they reveal high variation.
\end{abstract}

Keywords: Genetics, diversity, population, structure, indigenous, Aloe, species

\section{Introduction}

Kenya is known for its rich diversity of native Aloe species with 59 species being reported by [1]. The government of Kenya through the vision 2030 blue print, projects to curb food insecurity through sustainable management of dry lands and its genetic resources [2] which includes the Aloe species. The indigenous Aloe species are important non-wood plants with many economic and socio-cultural uses found in ASALs of Kenya which is home to more than $30 \%$ human population $[3,4]$. Due to their abundant socio-economic potential, the indigenous 
Adienge et al. Journal of Plant Science \& Molecular Breeding 2019,

http://www.hoajonline.com/journals/pdf/2050-2389-8-1.pdf

Aloe species in Kenya have been harvested by the local communities in the ASALs from their natural populations for many years for traditional medicinal use, cultural and aesthetic purposes [5]. The commercial exploitation of Aloe species in Kenya was first reported in the 1960 s with only five species being exploited for bitter gum production i.e. A. secundiflora, A. turkanesis, A. rivae, A. calidophila and A. scabrifolia $[6,7]$. Climate change, unsustainable harvesting of plants and their products, introduction of exotic species and pollution has been the key to unprecedented change in biodiversity worldwide [8]. This unsustainable extraction from the wild causes threat to ecological balance and finally, may lead to complete loss of the species. This has raised concern locally and internationally on the level and impact of exploitation of wild populations and prompted a Presidential decree in 1986, banning commercial harvesting of Aloe species from their natural populations [9].

Genetic diversity is a key component to biodiversity analysis and therefore it's important to have knowledge of the distribution, genetic diversity, environment and relations among plant varieties to recognize gene pools, identify gaps in germplasm collections and develop effective conservation and management strategies [10]. There are morphological variations in some economically important Aloe species [11]. The DNA based molecular markers are free from any environmental modulations unlike the morphological markers [12] and hence provide an important tool to determine the genetic diversity of Aloe species. The RAPD (Randomly Amplified Polymorphic DNA) and ISSR (Inter-Simple Sequence Repeat) marker systems have been widely used in genetic diversity studies of different plant species and offer alternative for studying genetic variation in Aloe species.

To address these challenges facing Aloe utilization in Kenya, this study therefore, determined the geographical distribution of the three commercial indigenous Aloe species (A. secundiflora, A. turkanensis, and A. scabrifolia) from selected areas in ASALs of Kenya to establish their distinct populations. In addition, the study evaluated the molecular characterization of the three Aloe species, using RAPDs and ISSR markers and mapped their genetic pools and structures. The output of this study was to provide important information in identifying gene pools, gaps in germplasm collections and development of effective conservation and management strategies for Aloe plants.

\section{Materials and methods}

\section{Description of the study area}

The study was carried out in selected ASALs of Kenya where Aloe species grow naturally in the wild with commercial exploitation for bitter gum production as shown below (Figure 1). The sampling populations came from Gwasi, Isebania, Kajiado, Laikipia, Loima, Lokitaung, Maralal, Mwingi, Oropoi, Samburu, Sultan Hamud, Baringo and Taveta (Figure 1).

\section{Sample collection from the field}

Young and healthy leaf tissues of 450 individual Aloe plants

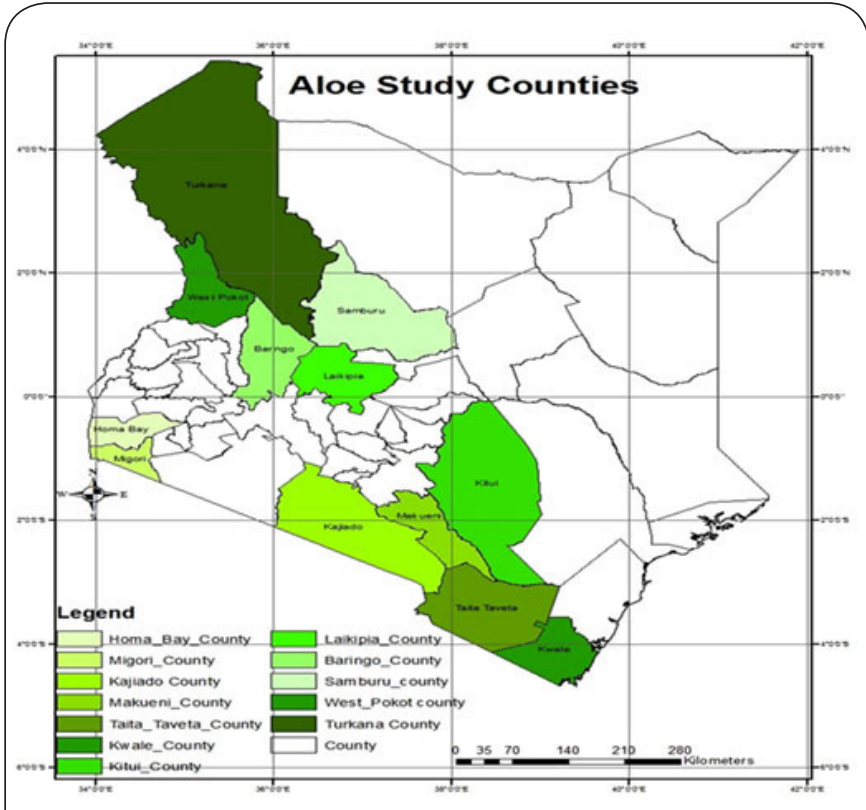

Figure 1. Aloe species distribution in the selected ASAL Counties of Kenya.

within the 15 populations were randomly sampled with each population represented by 30 plants. A distance of about 100 $\mathrm{m}$ apart was observed between each plant to avoid picking genetically related individuals. The samples were preserved in silica gel for DNA isolation in the laboratory. The GPS positions of each sampled plants were also recorded and sites mapped.

\section{DNA isolation and Polymerase Chain Reaction (PCR) analyses}

The modified cetyl trimethyl ammonium bromide (CTAB) method $[13,14]$ was used in this study. About $0.2 \mathrm{~g}$ of the dry leaf tissues were ground into fine powder using mixer mill (Retsch ${ }^{\circledast} \mathrm{MM} 400$ ) and then transferred to a $2.0 \mathrm{ml}$ microfuge tube containing 1,000 $\mu$ isolation buffer (IB, $10 \%$ polyethylene glycol, $0.35 \mathrm{M}$ sorbitol, $0.1 \mathrm{M}$ Tris- $\mathrm{HCl}-\mathrm{pH} 8.0$, and $0.5 \%$ $\beta$-mercapto-ethanol. The solution was mixed thoroughly by vortexing and then centrifuged at $10,000 \mathrm{rpm}$ at $4{ }^{\circ} \mathrm{C}$ for 3 minutes then supernatant transferred to a new sterile $2 \mathrm{ml}$ microfuge tube. Exactly $800 \mu$ l of isolation buffer (IB) was added and then vortexed to mix thoroughly and centrifuged at 10000 rpm at $4^{\circ} \mathrm{C}$ for 3 minutes and supernatant removed. This step was repeated 2-3 times till the supernatant was less viscous. About $500 \mu$ supernatant was taken and $500 \mu \mathrm{l}$ CTAB buffer (1\% CTAB, 0.05M Tris $\mathrm{HCl}, 0.7 \mathrm{M} \mathrm{NaCl}, 0.5 \% \beta$-mercaptoethanol, 24:1 chloroform: Isoamyl alcohol, sorbitol, $0.1 \mathrm{M}$ Tris-HCl-pH 8.0, and $10 \mathrm{ng} / \mu \mathrm{l}$ RNAse) added and mixed by vortexing and then incubated at $65^{\circ} \mathrm{C}$ for 60 minutes and another 30 minutes at $37^{\circ} \mathrm{C}$ in oscillating water bath for another 60 minutes. Equal volume ( $800 \mu \mathrm{l}$ ) of $\mathrm{CIA}$ (chloroform isoamyl alcohol; $24: 1$ ratio) was added and mixed thoroughly by gentle inversion for 20 minutes and centrifuged at $14,000 \mathrm{rpm}$ at room temperature 
for 10 minutes. $600 \mu$ l of supernatant was then transferred to a new $1.5 \mathrm{ml}$ microfuge tube and a tenth of $3 \mathrm{M} \mathrm{NaOAc}(60 \mu \mathrm{l}$ $\mathrm{NaOAc}$ ) and $600 \mu \mathrm{l}$ isopropanol added. The solution was mixed by gentle inversion and centrifuged $\left(15,000 \mathrm{rpm}\right.$ at $\left.4^{\circ} \mathrm{C}\right)$ for 5 minutes. The supernatant was discarded and $800 \mu \mathrm{l}$ of $70 \%$ ethanol added and flipped then centrifuged $(15,000 \mathrm{rpm}$ at $4^{\circ} \mathrm{C}$ ) for 5 minutes to wash the DNA pellets. The supernatant was discarded and the DNA pellets air dried for 45 minutes and dissolved in $300 \mu \mathrm{l}$ DNase-free water. The dissolved DNA was then quantified using spectrophotometer (Biospec-Nano) and then uniformly diluted to $6.25 \mu \mathrm{l}$ ready for PCR analysis.

\section{Polymerase Chain Reaction (PCR) analyses}

The polymerase chain reaction method was used as described by [15]. Forty RAPD and twenty five ISSR primers were screened for polymorphisms. Ten RAPD and seven ISSR primers which gave distinct polymorphic amplified products were selected for subsequent analysis. The PCR analysis of 10 RAPD and 7 ISSR loci (Table 1) was performed in a final volume of $6.25 \mu \mathrm{l}$. Approximately $6.25 \mathrm{ng}$ of template DNA was finally added in a $0.2 \mathrm{ml} 96$ well PCR microplate (Thermo Scientific AB-600). The reactions master mix composing of $1 \times$ PCR buffer (DreamTaq buffer), $3.5 \mathrm{mM} \mathrm{MgCl}_{2}$ (Qiagen), 0.4mM dNTPs (Biolabs), $0.24 \mu \mathrm{M}$ primers, 2\% PVP, $0.75 U$ Taq polymerase (Dream Taq) and 6.25ng template DNA was added. All the PCR reaction preparations were performed on ice. The RAPD thermal cycling was then done with first cycle starting with an initial denaturation at $95^{\circ} \mathrm{C}$ for 10 minutes, then followed by 35 cycles of denaturation at $95^{\circ} \mathrm{C}$ for 30 seconds, annealing at $37^{\circ} \mathrm{C}$ for 30 seconds and extension at $72^{\circ} \mathrm{C}$ for 1 minute. A final extension at $72^{\circ} \mathrm{C}$ was performed to make sure everything had polymerized. The
ISSR thermal cycling was done with first cycle starting with an initial denaturation at $95^{\circ} \mathrm{C}$ for 10 minutes, then followed by 35 cycles of denaturation at $95^{\circ} \mathrm{C}$ for 30 seconds, annealing at $47.5^{\circ} \mathrm{C}$ for 30 seconds and extension at $72^{\circ} \mathrm{C}$ for 1 minute.

A final extension at $72^{\circ} \mathrm{C}$ was performed to make sure everything had polymerized. The reactions were performed using Verity 96 thermo cycler (Applied Biosystems).

\section{Gel electrophoresis}

The gel electrophoresis method used was as described by $[16,17]$. Amplified fragments were separated using $1.4 \%$ agarose gel electrophoresis for 70 minutes. The gel was stained by adding 3.5 $\mu$ I SYBR Safe dye (Invitrogen 10,000x concentrate in DMSO) and molten in a microwave oven for 1 minute. DNA fragments were then mixed with $1 \times$ gel loading dye (Thermo Scientific) and then all $7.5 \mu \mathrm{l}$ were loaded into the gel well with the first and the last wells loaded with 100bp Plus DNA ladder (Thermo Scientific) for sizing the fragments. The gels were then viewed under UV illumination (ATTA E-Graph) at $320 \mathrm{~nm}$ and photographs taken.

\section{Data collection and statistical analysis}

For each RAPD and ISSR primer, only the stained bands which could be unambiguously scored were used in the analysis. The number of polymorphic and monomorphic fragments for each primer pair were visually scored (for band presence (1) or absence (0)) and set in a binary matrix. The binary matrix data file created was then configured as an input file for data analysis. The percentage of polymorphic loci $(\mathrm{P})$, polymorphic information content (PIC), Nei's genetic diversity index (H), coefficient of differentiation (Gst) were derived using PopGene

Table 1. Aloe species RAPD and ISSR primer oligonucleotide sequences and Polymorphic Information Content.

\begin{tabular}{|c|c|c|c|c|c|c|c|c|}
\hline $\begin{array}{l}\text { Primer } \\
\text { code }\end{array}$ & $\begin{array}{l}\text { Primer sequence } \\
5^{\prime} \rightarrow 3^{\prime}\end{array}$ & Type & $\begin{array}{l}\text { Total } \\
\text { bands }\end{array}$ & $\begin{array}{l}\text { polymorphic } \\
\text { bands }\end{array}$ & $\begin{array}{l}\% \text { of polymorphic } \\
\text { bands }\end{array}$ & $\begin{array}{l}\text { Total } \\
\text { fragments }\end{array}$ & $\begin{array}{l}\text { Polymorphic } \\
\text { fragments }\end{array}$ & $\begin{array}{l}\% \text { of polymorphic } \\
\text { fragments }\end{array}$ \\
\hline UBC-808 & AGAGAGAGAGAGAGAGC & ISSR & 9 & 8 & 88.89 & 1297 & 847 & 65.30 \\
\hline UBC-809 & AGAGAGAGAGAGAGAGG & ISSR & 10 & 9 & 90.00 & 2287 & 1837 & 80.32 \\
\hline UBC-811 & GAGAGAGAGAGAGAGAC & ISSR & 8 & 8 & 100.00 & 2197 & 2197 & 100.00 \\
\hline UBC-827 & ACACACACACACACACG & ISSR & 7 & 6 & 85.71 & 2274 & 1824 & 80.21 \\
\hline UBC-861 & ACCACCACCACCACCACC & ISSR & 11 & 11 & 100.00 & 3549 & 3549 & 100.00 \\
\hline UBC-873 & GACAGACAGACAGACA & ISSR & 13 & 13 & 100.00 & 4895 & 4895 & 100.00 \\
\hline UBC- 880 & GGAGAGGAGAGGAGA & ISSR & 13 & 12 & 92.31 & 5517 & 5067 & 91.84 \\
\hline KFP-3 & GTT AGC GGC G & RAPD & 13 & 12 & 92.31 & 3966 & 3516 & 88.65 \\
\hline KFP-10 & ACG GTG CGC C & RAPD & 15 & 9 & 60.00 & 5839 & 3139 & 53.76 \\
\hline KFP-8 & ACG CGC TGG T & RAPD & 11 & 5 & 45.45 & 4095 & 1395 & 34.07 \\
\hline KFP-17 & CCG AAG CCC T & RAPD & 16 & 11 & 68.75 & 5791 & 3541 & 61.15 \\
\hline KFP-21 & GTA GGC GTC G & RAPD & 9 & 4 & 44.44 & 3552 & 1302 & 36.66 \\
\hline KFP23 & GCT CGT CAA C & RAPD & 11 & 7 & 63.64 & 3835 & 2035 & 53.06 \\
\hline KFP-25 & CTA GGC GTC G & RAPD & 6 & 4 & 66.67 & 2076 & 1176 & 56.65 \\
\hline KFP-27 & TCC TCG CGG C & RAPD & 11 & 7 & 63.64 & 4102 & 2302 & 56.12 \\
\hline KFP-28 & AAT CGG GCT G & RAPD & 8 & 7 & 87.50 & 2378 & 1928 & 81.08 \\
\hline KFP-30 & GTG CGG ACA G & RAPD & 7 & 4 & 57.14 & 2102 & 752 & 35.78 \\
\hline
\end{tabular}


Adienge et al. Journal of Plant Science \& Molecular Breeding 2019,

http://www.hoajonline.com/journals/pdf/2050-2389-8-1.pdf

version 1.3.1 [18]. The analysis of molecular variance (AMOVA) and principal coordinate analysis were done using GenALEx software version 6.5 [19].

Mapping of the genetic pools of the three Aloe species To map the population genetic structure of the three Aloe species (turkanensis, scabrifolia and secundiflora), the combined ISSR and RAPD genetic binary data were used to estimate the exact number of subpopulations on the basis of the maximum assumed or estimated populations $(\Delta K)$ values. To outline the major gene pools, analyses were performed using admixture model assumptions with correlated alleles; $\mathrm{K}$ was presumed to be $2-10$, selected after 10 independent runs. Each run consisted of a burn-in period of 5,000 steps followed by 500,000 MCMC replicates [20]. The Structure Harvester statistical software [21] was used to collate the results obtained from Structure statistical software following [22] and maximum value of $\Delta \mathrm{K}$ associated with each $\mathrm{K}$ value were analyzed to identify the number of clusters that best described the data.

\section{Results and Discussion}

Geographical distribution of A. secundiflora, A. turkanensis, and A. scabrifolia from selected ASALs of Kenya and their distinct populations

The distributions of $A$. secundiflora, A. turkanensis and $A$. scabrifolia in the studied ASALs of Kenya were distinct. A. secundiflora was dominant in all of the surveyed sites i.e. Coast, Lake, Northern and Central regions. A. turkanensis and A. scabrifolia were only reported in Northern Kenya (Figure 2).

The distribution of Aloe secundiflora in Central, Coast and the lake Victora regions was mainly found in virgin uncultivated bush-lands and rocky hills, dominated by Acacia spp, Lantana

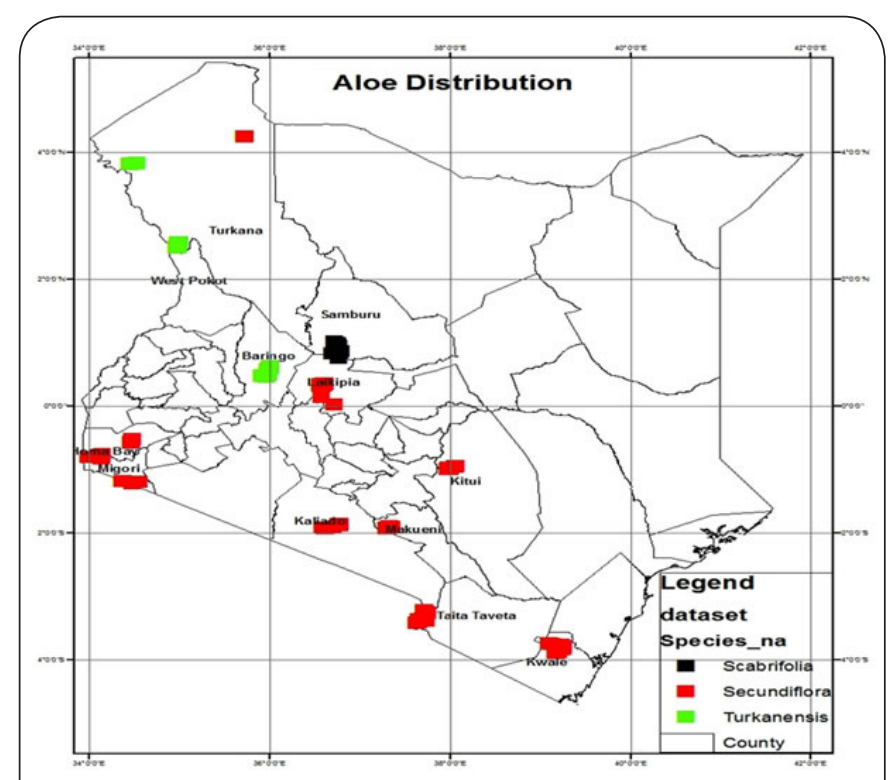

Figure 2. Geographical distribution of the three (3) Aloe species in the study areas in Kenya. camara, Agave spp, and other native Aloe spp under rocky loamy soils. However, in the Northern region, the distribution was mainly in rocky conserved forested hilly areas and bushy grasslands dominated by Acacia spp, Prosopis juliflora, Agave spp, Balanites aegyptica and other Aloe spp. The soils in these areas were mostly rocky and stony loams. The Aloe turkanensis was found mainly in the coastal belt of Kenya inhabiting mostly conserved forested lands dominated by Acacia spp, Prosopis juliflora and Agave spp.

Aloe scabrifolia was found distributed only in the Northern part of Kenya in Laikipia and Samburu Counties. The species was found to inhabit bushlands dominated by Acacia spp, Balanites aegyptica, Prosopis juliflora, Agave spp and other Aloe spp under rocky loamy soils.

The genus Aloe is known mostly to be associated with dry habitats with few species colonizing the subtropics. The results about distribution from this study are in agreement with other findings $[23,24]$. However, Aloe species is reported to also thrive under closed-canopy forests at altitudes of $2700 \mathrm{~m}$ absl [24]. The distribution of the three Aloe species studied seemed to follow a particular geographical range whereby $A$. turkanensis and A. scabrifolia were found distributed only to the North of the equator while Aloe secundiflora seemed to colonize both the North and South hemispheres $[6,25]$ reported that the East Africa region alone had about 83 species of Aloe and approximately 60 species growing naturally in the dryland zones of Kenya. From this study, different Aloe species were found growing naturally in abundance in several Counties in Kenya including Baringo, Samburu, West Pokot, Turkana, Laikipia, Homabay, Migori, Kwale and Taita Taveta. [26] Found Aloe species growing naturally in Nyeri, Kiambu, Machakos, Kitui and western and coast regions of Kenya. [5], reported Aloe species habitat preferences in Kenya with $66 \%$ occurring in deciduous bushland/woodlands, $14 \%$ in grasslands while $20 \%$ for thickets, riverine woodlands and scrubland or rock outcrops. The same study revealed that the highest proportion of aloes (32\%) occurred between 100-1500 m above sea level.

From other studies by [5], A. secundiflora occurs mostly in grassland and deciduous woodlands in both relatively wet to arid climatic zones and less in marshy or water-logged environments. Both A. scabrifolia and A. turkanensis are believed to be localized (special habitat), mostly found in harsher and more arid climates especially in northern Kenya, Southern Ethiopia and eastern Uganda, [5]. Such reports agree with the findings in this study whereby A. turkanensis and A. scabrifolia were found distributed only to the North of the equator (northern Kenya). In Kenya, population census for many specific Aloe species is lacking and hence difficulties in providing reliable estimates of population size important for conservation or even commercialization. Studies by [7] estimated population of commercial Aloe species to be 129 million plants, $83 \%$ of which were $A$. secundiflora. The other commercial species of interest like $A$. turkanensis, A. calidophila and $A$. rivae accounted for only $0.1 \%$ while the $A$. scabrifolia listed as endemic [5] 
was estimated at $16.9 \%$ of the total count. The geographical distribution of most plants is influenced mostly by both edaphic and climatic factors.

Since the soil type differs a lot in different ecological zones, perhaps this explains why the $A$. turkanensis and $A$. scabrifolia were found distributed in Northern Kenya as the soils are nearly similar in Turkana, Baringo and Samburu Counties compared to the coastal areas of Kenya. Therefore, it is recommended to undertake biophysical studies among the three commercial Aloe species to help in determining why the $A$. secundiflora was dominant when compared the other species.

Molecular characterization of the three commercial Kenyan Aloe species, using RAPD and ISSR markers species

In this study, all populations revealed clear polymorphism over the primers used as shown in Table 1. The Nei's genetic diversity indices for the combined markers (ISSR and RAPD) ranged from 0.112 to 0.177 in Baringo-TUR and Maralal-Sec populations respectively (Table 2 ). The percentage of polymorphic bands observed within the populations also ranged from $33.71 \%$ to $51.12 \%$. The average gene diversity index among the population $\left(\mathrm{G}_{\mathrm{st}}\right)$ was revealed to be $41 \%$ (Table 2) from both the RAPD and ISSR bands.

The highest genetic similarities were recorded between Kajiado and Gwasi, Laikipia-SEC and Isebania, and maralal-SEC and Kajiado populations at 0.996 while the lowest similarities were recorded between Laikipia-SCAB and Laikipia-SEC at 0.575 . The hierarchical cluster analysis (UPGMA) categorized populations into three main groups (Figure 3 ). The first cluster A comprised of Baringo-TUR, Loima-TUR and Oropoi-TUR populations. The second cluster B consisted of Gwasi, Samburu, Isebania, Kajiado, Laikipia-SEC, Sultan, Lokitaung, Mwingi, Maralal SEC and Taveta populations. The last cluster C comprised of Laikipia SCAB and Maralal SCAB populations. The principal coordinate analysis ( $\mathrm{PCOA}$ ) performed on combined

Table 2. Population Genetic parameters: percentage of polymorphic band(s), Nei's genetic diversity $(\mathrm{H})$, Nei's genetic differentiation index among populations (Gst).

\begin{tabular}{|c|c|c|c|c|c|c|}
\hline & \multicolumn{2}{|r|}{ RAPD } & \multicolumn{2}{|r|}{ ISSR } & \multicolumn{2}{|c|}{ RAPD \& ISSR } \\
\hline & $\mathbf{H}$ & $\begin{array}{l}\% \text { of polymorphic } \\
\text { bands }\end{array}$ & $\mathbf{H}$ & $\begin{array}{l}\% \text { of polymorphic } \\
\text { bands }\end{array}$ & $\mathbf{H}$ & $\begin{array}{l}\% \text { of polymorphic } \\
\text { bands }\end{array}$ \\
\hline BARINGO TUR & $\begin{array}{l}0.0961 \\
(0.1568)\end{array}$ & 37.38 & $\begin{array}{l}0.1361 \\
(0.1741)\end{array}$ & 52.11 & $\begin{array}{l}0.1121 \\
(0.1646)\end{array}$ & 43.26 \\
\hline GWASI & $\begin{array}{l}0.1398 \\
(0.1863)\end{array}$ & 42.99 & $\begin{array}{l}0.2044 \\
(0.1929)\end{array}$ & 63.38 & $\begin{array}{l}0.1656 \\
(0.1911)\end{array}$ & 51.12 \\
\hline ISEBANIA & $\begin{array}{l}0.1231 \\
(0.1782)\end{array}$ & 40.19 & $\begin{array}{l}0.1817 \\
(0.1915)\end{array}$ & 59.15 & $\begin{array}{l}0.1465 \\
(0.1853)\end{array}$ & 47.75 \\
\hline KAJIADO & $\begin{array}{l}0.1431 \\
(0.1870)\end{array}$ & 42.99 & $\begin{array}{l}0.2094 \\
(0.1923)\end{array}$ & 63.38 & $\begin{array}{l}0.1695 \\
(0.1914)\end{array}$ & 51.12 \\
\hline LAIKIPIA SEC & $\begin{array}{l}0.1196 \\
(0.1752)\end{array}$ & 39.25 & $\begin{array}{l}0.1763 \\
(0.1889) \\
\end{array}$ & 57.75 & $\begin{array}{l}0.1422 \\
(0.1824)\end{array}$ & 46.63 \\
\hline LAIKIPIA SCAB & $\begin{array}{l}0.1279 \\
(0.2013)\end{array}$ & 29.91 & $\begin{array}{l}0.1201 \\
(0.1673)\end{array}$ & 39.44 & $\begin{array}{l}0.1247 \\
(0.1880)\end{array}$ & 33.71 \\
\hline LOIMA TURK & $\begin{array}{l}0.1022 \\
(0.1678)\end{array}$ & 33.64 & $\begin{array}{l}0.1411 \\
(0.1860)\end{array}$ & 45.07 & $\begin{array}{l}0.1177 \\
(0.1758)\end{array}$ & 38.2 \\
\hline LOKITAUNG & $\begin{array}{l}0.1293 \\
(0.1816)\end{array}$ & 40.19 & $\begin{array}{l}0.1898 \\
(0.1926)\end{array}$ & 59.15 & $\begin{array}{l}0.1534 \\
(0.1879)\end{array}$ & 47.75 \\
\hline MARALAL SCAB & $\begin{array}{l}0.1310 \\
(0.2055)\end{array}$ & 29.91 & $\begin{array}{l}0.1433 \\
(0.1937)\end{array}$ & 39.44 & $\begin{array}{l}0.1359 \\
(0.2004) \\
\end{array}$ & 33.71 \\
\hline MARALAL SEC & $\begin{array}{l}0.1498 \\
(0.1923)\end{array}$ & 42.99 & $\begin{array}{l}0.2190 \\
(0.1958)\end{array}$ & 63.38 & $\begin{array}{l}0.1774 \\
(0.1961)\end{array}$ & 51.12 \\
\hline MWINGI & $\begin{array}{l}0.1236 \\
(0.1778)\end{array}$ & 40.19 & $\begin{array}{l}0.1823 \\
(0.1908)\end{array}$ & 59.15 & $\begin{array}{l}0.1470 \\
(0.1848)\end{array}$ & 47.75 \\
\hline OROPOI TUR & $\begin{array}{l}0.1124 \\
(0.1711)\end{array}$ & 37.38 & $\begin{array}{l}0.1567 \\
(0.1886)\end{array}$ & 49.3 & $\begin{array}{l}0.1301 \\
(0.1791)\end{array}$ & 42.13 \\
\hline SAMBURU & $\begin{array}{l}0.1439 \\
(0.1899)\end{array}$ & 42.99 & $\begin{array}{l}0.2099 \\
(0.1951)\end{array}$ & 63.38 & $\begin{array}{l}0.1702 \\
(0.1942)\end{array}$ & 51.12 \\
\hline SULTAN & $\begin{array}{l}0.1320 \\
(0.1858)\end{array}$ & 40.19 & $\begin{array}{l}0.1944 \\
(0.1978)\end{array}$ & 59.15 & $\begin{array}{l}0.1569 \\
(0.1926)\end{array}$ & 47.75 \\
\hline TAVETA & $\begin{array}{l}0.1446 \\
(0.1879)\end{array}$ & 42.99 & $\begin{array}{l}0.2116 \\
(0.1928)\end{array}$ & 63.38 & $\begin{array}{l}0.1713 \\
(0.1922)\end{array}$ & 51.12 \\
\hline $\begin{array}{l}\text { Gene diversity } \\
\text { among populations } \\
\text { (Gst) }\end{array}$ & 0.37 & & 0.4 & & 0.41 & \\
\hline
\end{tabular}

$\mathrm{H}$ represents Nei's genetic diversity index within the population. Standard deviations are in () 
Adienge et al. Journal of Plant Science \& Molecular Breeding 2019,

http://www.hoajonline.com/journals/pdf/2050-2389-8-1.pdf

doi: $10.7243 / 2050-2389-8-1$

binary data for RAPD and ISSR grouped the populations into three major clusters similar to the hierarchical cluster analysis (Figure 4).

Similarly, the analysis of molecular variance (AMOVA) calculated using Genalex 6.5 on the Nei's similarity matrices from the combined RAPD and ISSR primers, revealed significant variations $(P>0.01)$ within and among populations at $58 \%$ and $42 \%$ respectively (Table 3 ).

Genetic diversity represents the heritable variation within and among populations of organisms. For effective plant breeding and germplasm collection, there is need to understand the extent of genetic diversity [27]. Molecular marker analysis is a reliable tool for assessment of genetic diversity

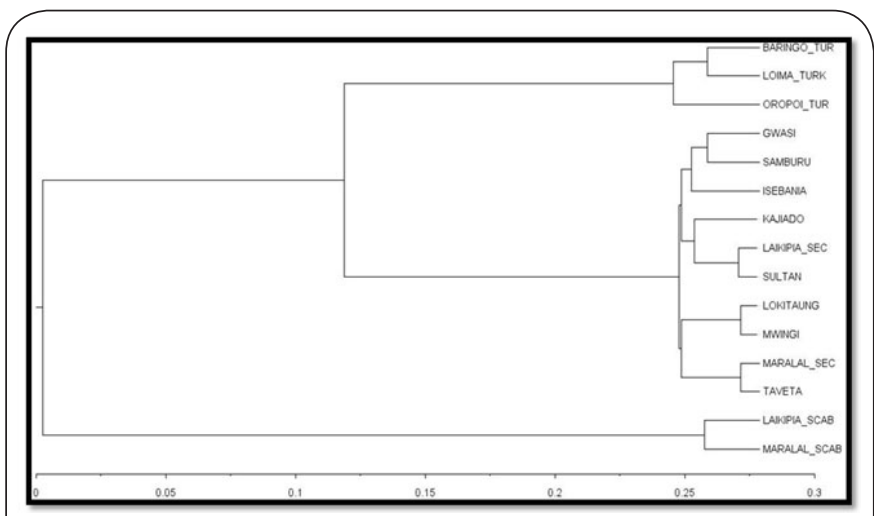

Figure 3. Dendrogram (UPGMA) representing genetic relationships among 15 populations of three indigenous Aloe species based on Nei's genetic similarity indices obtained using pooled combined RAPD and ISSR primers.

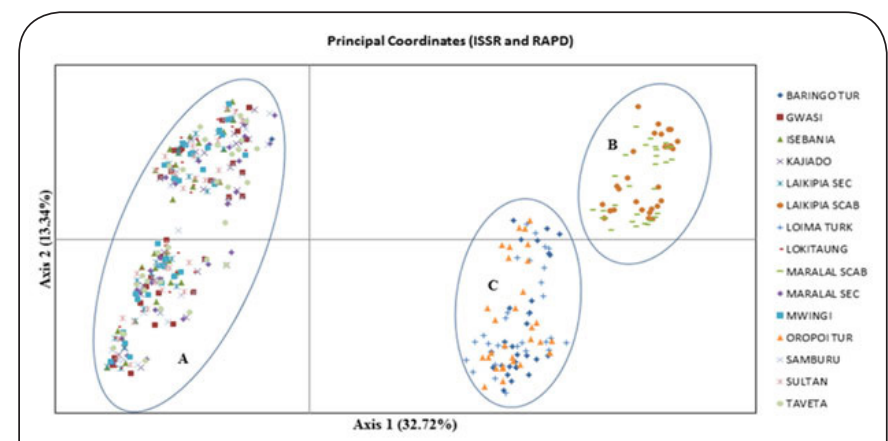

Figure 4. Two-dimensional scaling of Aloe populations by principal coordinate analysis using pooled data from combined RAPD and ISSR markers.

Table 3. Analysis of Molecular Variance (AMOVA).

\begin{tabular}{lllllll}
\hline Source of variation & df & SS & MS & Est. Var. & $\begin{array}{l}\boldsymbol{P} \text { (rand } \\
>=\text { data) }\end{array}$ \\
\hline Among Pops (ISSR) & 14 & 2287.9 & 163.43 & 5.23 & 0.44 & .001 \\
Among Pops (RAPD) & 14 & 2004.3 & 143.17 & 4.54 & 0.39 & .001 \\
$\begin{array}{l}\text { Among pops } \\
\text { (RAPD and ISSR) }\end{array}$ & 14 & 4292.3 & 306.59 & 9.77 & 0.42 & .001 \\
\hline
\end{tabular}

among taxa but traditional methods like morphological traits have proved to be relatively less reliable and inefficient for discrimination of closely related genotypes in Aloe species [28]. Therefore, selection based genetic information using molecular markers is more reliable and consistent.

This study also characterized fifteen Aloe populations using RAPD and ISSR markers to ascertain the genetic diversity within and among them for conservation, management and sustainable utilization of Aloes. The results revealed that all the loci detected by both RAPD and ISSR markers in Aloe species genotypes were polymorphic. A higher percentage of polymorphism was revealed by ISSR markers in comparison to RAPD markers ( $94 \%$ and $65 \%$ respectively). The percentage of polymorphic bands observed within the fifteen populations ranged from $29 \%$ to $42 \%$ in RAPD and $39 \%$ to $63 \%$ in ISSR markers. Similar findings have been reported in various studies; [29] obtained a higher polymorphism using ISSR markers (80.9\%) than RAPD $(71.8 \%)$ while studying genetic diversity of Aloe vera. However, low levels of polymorphism using both ISSR and RAPD markers were reported in Bruguirra gymnorrhiza and Heritiera fomes [30]. Most studies on wild plant populations have used the percentage of polymorphism as an indicator of genetic diversity [31]. However, [32] indicated that the percentage polymorphism is not a significant measure of genetic variation and that the parameter of genetic diversity $(\mathrm{H})$ is more applicable.

In addition, there was also a higher variance in genetic diversity within populations than among populations when the RAPD, ISSR and when both markers were used. In this study, both ISSR and RAPD revealed significant variations among the Aloe populations yielding $44 \%$ and $39 \%$ respectively.

The combined ISSR and RAPD markers yielded $42 \%$ genetic variation among the fifteen populations. Since RAPD and ISSR markers have different strengths, it has been proposed that a combination of both markers in genetic studies is desirable for more accurate results. [33], reported the different abilities of ISSR and RAPD markers in discriminating different genotypes. The combination of markers might be a good approach due to the different regions targeted by each marker allowing for wide genome coverage in genetic variability studies. The ISSR markers have been reported to be highly reproducible and produce more complex banding patterns than RAPD [34-36]. In addition, the RAPD markers are known to cover the entire genome of coding and non-coding regions while ISSR markers reveal polymorphisms from sequences between two microsatellite primer sites $[13,37])$ and thus important when differentiating closely related cultivars or species. In the past, researchers have reported genetic diversity studies in Aloe species using RAPD and ISSR markers among other different marker systems. This is because of their simplicity, rapidness, affordability and can be applied without any prior knowledge regarding the plant genome [29,38]. Both RAPD and AFLP (Amplified Fragment Length Polymorphism) markers have also been used to study the genetic diversity among different Aloe species $[39,40]$. In 
India, $[\mathbf{2 8 , 4 1}]$ used RAPD and AFLP markers to assess genetic diversity among Aloe accessions from different geographical regions. Similar results have been reported by [10] and [29] on genetic variability in Aloe vera where both RAPD and ISSR primers have been used.

Moreover, in this study, there was genetic diversity in each population as revealed by the Nei's genetic diversity indices (H) which varied between the ISSR and RAPD markers. The RAPDs revealed genetic diversity ranging from 0.0961 (Baringo Tur) to 0.1498 (Maralal Sec), while ISSR markers ranged from 0.1201 (Laikipia Scab) to 0.219 (Maralal Sec). With the combined effects of the two markers, the genetic diversity indices within the populations ranged from 0.1121 (Baringo Tur) to 0.1774 (Maralal Sec). The higher genetic diversity recorded by the ISSR markers as compared to RAPD was attributed to its high power of discriminating between closely related genotypes [33]. The Nei's genetic diversity indices $(\mathrm{H})$ also revealed high variation among individuals within a single population as observed with the average gene diversity among populations (Gst) being revealed at 0.37 and 0.4 for RAPD and ISSR markers respectively.

The genetic diversity results were in line with those of molecular variance analysis whereby, the variations among the populations were highly significant when both markers were used combined or separate. This therefore, indicated that the major factors endangering the survival of Aloe species in Kenya are both ecological and anthropogenic as supported by [42]. The pattern of genetic variations as portrayed by the genetic indices among the populations in this study might also be attributed to the cumulative genetic changes within each population and the difference in species. The results obtained could also be attributed to the pollination, propagation and seed dispersal mechanisms of Aloe species as they reproduce both vegetatively and by seed. This phenomenon combined with the long-lived perennial habit of the plants leads to predominance of older plants in Aloe populations $[7,43]$.

In addition, the distribution of Aloe species is affected by the presence of specific pollinators and by seed morphology [44] whereby, some Aloe seeds such as those of Aloe excelsa have large, efficient wings that aid dispersal, and may account for their widespread distribution [44]. Other species such as Aloe aculeata produce wingless seeds, seemingly limiting their dispersal, thus resulting in dense stands of plants in localized areas [44]. Reduction and fragmentation in conserved forested landscapes and over-exploitation have been cited as the main causes leading to increased genetic differentiation and reduced gene flow between populations [45].

In conclusion, the ability to resolve genetic variation among different genotypes may be directly related to the number of polymorphisms detected with each marker technique. Therefore, studies on genetic variation in Aloe species should prioritize the combined use of both ISSR and RAPD markers as they reveal high variation when employed together. This will help in undertaking conservation measures especially ex-situ for those populations with economic importance like the Maralal SEC (secundiflora) population which had the highest genetic diversity.

Mapping of the genetic pools for the three commercial Aloe species (A. secundiflora, A. turkanensis, and A. scabrifolia) in ASALs of Kenya

In mapping the population genetic structure of the three Aloe species (turkanensis, scabrifolia and secundiflora), the genetic binary data for combined ISSR and RAPD markers were used to estimate the exact number of subpopulations on the basis of the maximum assumed or estimated populations $(\Delta K)$ values. Three groups were formed at $K=3$, which corresponded to the three Aloe species used in the study as shown in Figure 5 and Table 4. The exact number of populations based on gene pool proximity was assessed by Structure Harvester software using admixture model assumptions with maximum $\Delta \mathrm{K}$ value observed at $\mathrm{K}=3$ (1569.3) as shown in Table 4. The Aloe turkanensis clustered in the first group (red), followed by Aloe scabrifolia (Green) and then Aloe secundiflora (Blue) as shown in Figures 6-9 based on genetic structure and the hierarchical UPGMA analysis.

This study exhibited a population genetic structure with three major clusters which corresponded to the three Aloe

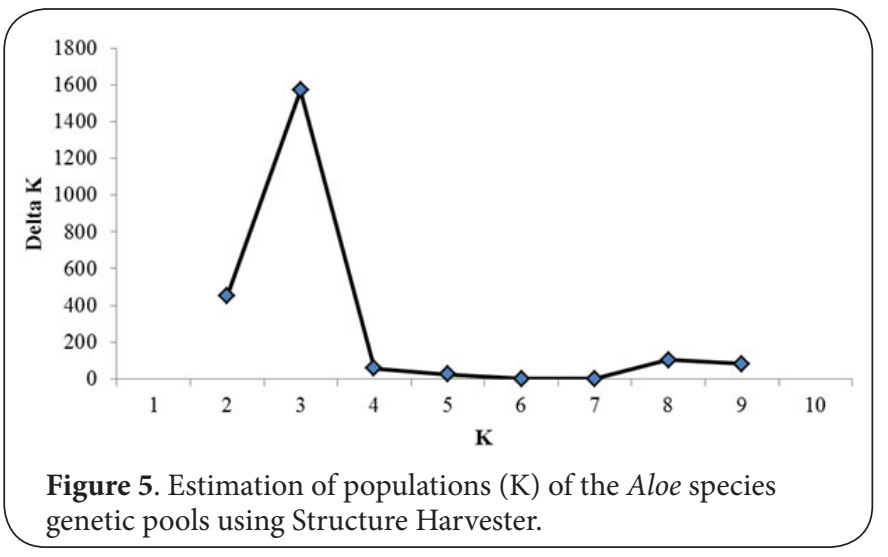

Table 4. Mapping of the Aloe species genetic pools using Structure Harvester.

\begin{tabular}{llllll}
\hline K & Mean LnP(K) & Stdev LnP(K) & Ln'(K) $^{\prime}$ & $\left|\operatorname{Ln}^{\prime}(K)\right|$ & Delta K \\
\hline 1 & -30756.8 & 0.353553 & - & - & - \\
2 & -18597.9 & 3.394113 & 2916.75 & 1537.55 & 453.005 \\
3 & -21514.7 & 4.030509 & 9242.1 & 6325.35 & 1569.368 \\
4 & -17218.7 & 5.515433 & 1379.2 & 322.9 & 58.54482 \\
5 & -16162.4 & 25.59727 & 1056.3 & 641.2 & 25.04955 \\
6 & -14464.9 & 1751.221 & 1697.5 & 1142.25 & 0.652259 \\
7 & -13909.7 & 1503.38 & 555.25 & 1163.6 & 0.773989 \\
8 & -12190.8 & 34.78965 & 1718.85 & 3555.1 & 102.1884 \\
9 & -14027.1 & 56.9221 & -1836.25 & 4672.1 & 82.07885 \\
10 & -11191.2 & 115.5412 & 2835.85 & - & - \\
\hline
\end{tabular}




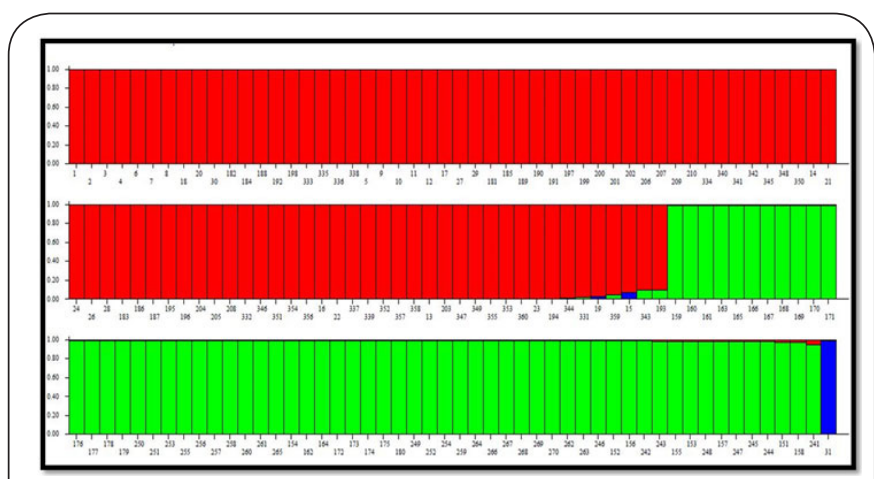

Figure 6. Mapping of the Aloe species genetic pools using Structure Harvester.

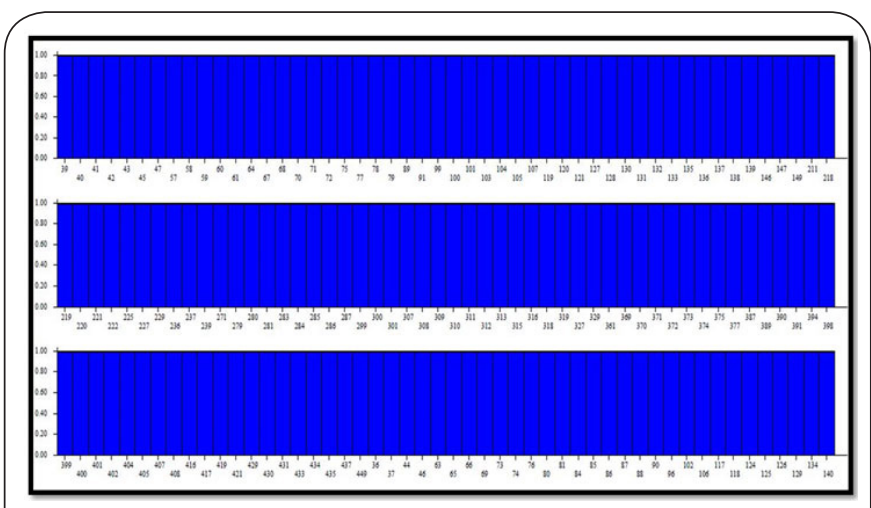

Figure 7. Mapping of the Aloe species genetic pools using Structure Harvester.

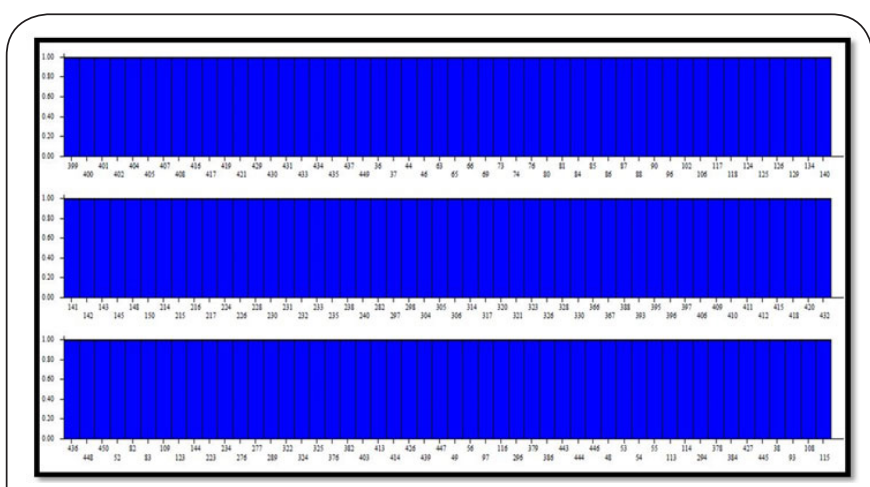

Figure 8. Mapping of the Aloe species genetic pools using Structure Harvester.

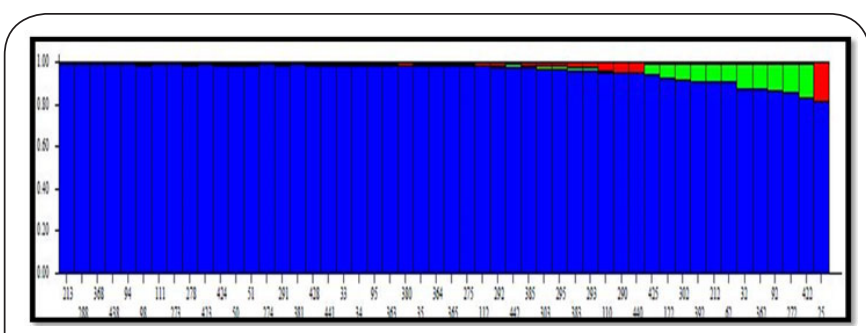

Figure 9. Mapping of the Aloe species genetic pools using Structure Harvester. species (turkanensis, scabrifolia and secundiflora). The maximum assumed or estimated populations $(\Delta \mathrm{K})$ value was observed for $\mathrm{K}=3$ corresponding to the three Aloe species studied. The overall membership proportion showed very minimal reproductive crossing between the Aloe species. The three clusters based on genetic structure and the hierarchical analysis for all the populations corresponded mostly with one another with respect to their pedigree relationships. However, the population genetic structure better explains the relationships because of the higher degree of simulation as explained by [21]; whereby, groupings based on larger value of $\Delta \mathrm{K}$ could describe the number of subpopulations best fitted with the data rather than the higher $\operatorname{LnP}(K)$ value. The $\operatorname{LnP}(K)$ value estimates the posterior probability of the simulations which is then used to estimate the number of populations detected in the sample [46]. The genetic similarity analysis had also discriminated the Aloe populations into three broad clusters despite the high molecular variation among the fifteen populations. Both the principal coordinate and the UPGMA cluster analysis for each and the combined markers were in agreement from the results. These high variations could be attributed to, (i) the different Aloe species found in the different fifteen populations studied or (ii) the variations within each population as a result of genetic drift in a bid to adapt to new environment(s) through the loss of some alleles with successive generations in some populations.

According to [47], gene mapping is a process which allocates a relative position on a chromosome and the maps are speciesspecific comprised of gene markers and/or genes and the genetic distance between each marker. However, the genetic distances are said to be calculated based on the frequency of chromosome crossovers occurring during meiosis, and not on their physical location on the chromosome. The gene mapping or clustering a population structure is influenced by many factors including number of markers, sample sizes, the number of clusters and, allele frequency correlations etc. [48]. The mapping of the genetic structure may have also influenced the outcome of the genetic structure especially the model used either, Admixture or no Admixture models. In this study, Admixture model by the Structure Harvester Software was used to map the genetic data from the 15 populations. The Admixture model assumes individuals have an admixed ancestry whereby, each individual can inherit a fraction of their genome from ancestors in the population. However, [49] reported that the model ignores possible correlations in ancestry that occur in segments of each chromosome. In addition, the number of simulated clusters on the genetic data especially when employing the multidimensional scaling statistical methods influences the genetic structure [50].

Genetic diversity is simply the differences that occur among individuals of a species in the expression of a certain trait or set of traits and is crucial to population survival a given environment $[\mathbf{5 1}, \mathbf{5 2}]$. The interactions of individuals or populations may cause development of structures in species which is re- 
vealed in the variability distributed within and among natural or artificial populations. For efficient conservation genetics management, it is important to involve population genetics models to save the threatened species from extinction [53]. Genetic variability is influenced by environmental factors such as edaphic, geographical and seasonal [54]. The adaptation of an organism to environmental changes requires a pool of variable genes in a population to withstand selective pressure [55]. The Aloe species are widely distributed in different habitats with varied edaphic and seasonal conditions [5] with their distribution indicating inherent genetic diversity that boosts adaptation to these conditions.

Mutations play a vital role in generation of new alleles in a population and this is geared by the evolutionary factors; natural selection, genetic drift and migration [53]. Thus, for success of any genetic conservation and breeding program, identification of the amount and distribution of genetic diversity in the gene pool of the concerned plant is important [10]. In conclusion, all these factors above may have resulted in the narrow and common gene pool in the three Aloe species populations. The differences in the results obtained may also be due to the fact that the two markers used target different portions of the genome [15,37].

\section{Conclusions}

From the results the following conclusions were made: $A$. secundiflora species was the most distributed in the studied ASALs of Kenya among the three Aloe species, being dominant in Coast, Lake and Central regions. There was high genetic variation among and within the studied populations. The genetic variation was highest within $A$. secundiflora species and least within A. turkanensis species. Maralal population had the highest genetic variation. The combined use of ISSR and RAPD markers revealed high genetic variation among the populations as compared to when either of them was used singly. The study exhibited a population genetic structure with three major clusters which corresponded to the three Aloe species (turkanensis, scabrifolia and secundiflora) with the overall membership proportion showing very minimal reproductive crossing between the Aloe species. It is therefore, recommended to undertake biophysical studies among the three Aloe species to help in determining why the Aloe secundiflora was dominant. In addition, ex-situ conservation for Aloe turkanensis should be undertaken as it had the least genetic variation and it was less distributed geographically. The Maralal sec population should also be conserved as it had high genetic diversity. Finally, studies on genetic variation in Aloe species should prioritize the combined use of both ISSR and RAPD markers as they reveal high variation when employed together.

\section{Competing interests}

The authors declare that they have no competing interests.

Authors' contributions
\begin{tabular}{|l|c|c|c|c|c|c|}
\hline Authors' contributions & AA & GM & SN & JG & JK & JN \\
\hline Research concept and design & $\checkmark$ & $\checkmark$ & -- & -- & $\checkmark$ & $\checkmark$ \\
\hline Collection and/or assembly of data & $\checkmark$ & -- & -- & $\checkmark$ & -- & -- \\
\hline Data analysis and interpretation & $\checkmark$ & -- & $\checkmark$ & $\checkmark$ & -- & -- \\
\hline Writing the article & $\checkmark$ & -- & $\checkmark$ & -- & -- & -- \\
\hline Critical revision of the article & -- & $\checkmark$ & $\checkmark$ & -- & $\checkmark$ & $\checkmark$ \\
\hline Final approval of article & $\checkmark$ & $\checkmark$ & $\checkmark$ & $\checkmark$ & $\checkmark$ & $\checkmark$ \\
\hline
\end{tabular}

Acknowledgement

The authors acknowledge the Kenya Forestry Research Institute (KEFRI) for providing research funds for this study.

Publication history

EIC: Klaus Palme, University of Freiburg, Germany.

Received: 16-Oct-2019 Final Revised: 18-Nov-2019

Accepted: 20-Nov-2019 Published: 13-Dec-2019

\section{References}

1. Carter S, Lavranos JJ, Newton LE and Walker CC. Aloes The Definitive Guide. Royal Botanic Gardens. Kew: Kew Publishing. 2011.

2. Government of Kenya (GoK). Drought monthly bulletin. Isiolo district. 2007.

3. Muturi GM. Ecological impacts of Prosopis invasion in Riverine Forests of Kenya. PhD Thesis, Wageningen University, Netherlands. 2012.

4. Mayaux $\mathrm{P}$, Holmgren $\mathrm{P}$, Achard F, Eva H, Stibig HJ and Branthomme A. Tropical forest cover change in the 1990s and options for future monitoring. Philos Trans R Soc Lond B Biol Sci. 2005; 360:373-84. | Article | PubMed Abstract | PubMed FullText

5. Wabuyele E and Kyalo S. Sustainable use of East African Aloes: the case of commercial Aloes in Kenya. In NDF Workshop Case Studies, WG3Succulents and Cycads 2008. 2019. I Pdf

6. Wabuyele E, Bjorå CS, Nordal I and Newton LE. Distribution, diversity and conservation of the genus Aloe in Kenya. J. East Afr. Nat. Hist. 2006; 95:213-225.

7. Lubia IK, Kyalo SN, Mukonyi KW, Lusweti AM and Situma CA. Strategy for conservation and management of commercial Aloe species in Kenya. Kenya Wildlife Services. 2008; 60. I Website

8. Brooks TM, Mittermeier RA, Mittermeier CG, Da Fonseca GA, Rylands AB, Konstant WR, Flick P, Pilgrim P, Oldfield S, Magin G and Hilton-Taylor C. Habitat loss and extinction in the hotspots of biodiversity. Asian J. Conserv. Biol 2002; 4:909-923.

9. Nyamora P. Medicinal plant given presidential protection. Daily Nation (Kenya). 1986; 8075:1-24.

10. Nayanakantha NC, Singh BR and Gupta AK. Assessment of genetic diversity in Aloe germplasm accessions from India using RAPD and morphological markers. J. Cell Sci. 2010; 39:1-9.

11. Das S, Mishra B, Gill K, Ashraf MS, Singh AK, Sinha M, Sharma S, Xess I, Dalal K, Singh TP and Dey S. Isolation and characterization of novel protein with anti-fungal and anti-inflammatory properties from Aloe vera leaf gel. Int J Biol Macromol. 2011; 48:38-43. | Article | PubMed

12. Duminil J and Di Michele M. Plant species delimitation: A comparison of morphological and molecular markers. Plant Biosyst. 2009; 143:528-542.

13. Shiraishi $S$ and Watanabe A. Identification of chloroplast genome between Pinus densiflora Sieb. et Zucc. and P. thunbergii Parl. Based on the polymorphism in rbcL GENE. J. Jap. Forestry Soc. 1995; 77:429-436 (in Japanese with English summary). I Website

14. Hanaoka S, Muturi GM and Watanabe A. Isolation and characterization of microsatellite markers in Melia volkensii Gurke. Conserv. 2012; 4:395398. | Article

15. Williams JG, Kubelik AR, Livak KJ, Rafalski JA and Tingey SV. DNA polymorphisms amplified by arbitrary primers are useful as genetic markers. Nucleic Acids Res. 1990; 18:6531-5. I Article I PubMed Abstract 
Adienge et al. Journal of Plant Science \& Molecular Breeding 2019,

http://www.hoajonline.com/journals/pdf/2050-2389-8-1.pdf

doi: $10.7243 / 2050-2389-8-1$

\section{PubMed FullText}

16. McDonell MW, Simon MN and Studier FW. Analysis of restriction fragments of T7 DNA and determination of molecular weights by electrophoresis in neutral and alkaline gels. J Mol Biol. 1977; 110:11946. | Article | PubMed

17. Southern E. Gel electrophoresis of restriction fragments. Methods Enzymol. 1979; 68:152-76. | Article | PubMed

18. Yeh FC. POPGENE. Microsoft Window-Bases Freeware for Population Genetic Analysis. Version, 1. 31. 1999.

19. Peakall R and Smouse PE. GenAIEx 6.5: genetic analysis in Excel. Population genetic software for teaching and research--an update. Bioinformatics. 2012; 28:2537-9. | Article | PubMed Abstract | PubMed FullText

20. Pritchard JK and Wen W. Documentation for Structure software. Version 2. 2003. | Article

21. Earl DA and VonHoldt BM. Structure Harvester: a website and program for visualizing Structure output and implementing the Evanno method. Conserv. 2012; 4:359-361. | Article

22. Evanno $G$, Regnaut $S$ and Goudet J. Detecting the number of clusters of individuals using the software STRUCTURE: a simulation study. Mol Ecol. 2005; 14:2611-20. | Article | PubMed

23. Van-Jaarsveld EJ. Tylecodon ellaphieae. The Flowering Plants of Africa 50: Plate 1983; 1989.

24. Sachedina $\mathrm{H}$ and Bodeker G. Wild Aloe harvesting in South Africa. J Altern Complement Med. 1999; 5:121-3. | Article | PubMed

25. Carter S. Aloaceae. In R.M. Polhill (ed.) Flora of Tropical East Africa. Balkema, Rotterdam. 1994.

26. Mukonyi KW, Situma CA, Lusweti A, Kyalo S and Khamala E. Wild Aloe resource Base in Kenyan and Ugandan Drylands as Alternative Livelihoods for Rural Communities. J. Disc. Innov. 2007.

27. Wu J, Krutovskii KV and Strauss SH. Nuclear DNA diversity, population differentiation and phylogenetic relationships in the Califonia closedclone pines based on RAPD and allozyme markers. Genome. 1999; 42:893-908. | Article

28. Nejatzadeh-Barandozi F, Naghavi MR, Enferadi ST, Mousavi A, Mostofi $Y$ and Hassani ME. Genetic diversity of accessions of Iranian Aloe vera based on horticultural traits and RAPD markers. Ind crop prod. 2012; 37:347-351. | Article

29. Bhaludra CS, Yadla H, Cyprian FS, Bethapudi RR, Basha SD and Anupalli RR. Genetic diversity analysis in the genus Aloe vera (L.) using RAPD and ISSR markers. Int J. pharmacol. 2014; 10:479-486. | Article

30. Dasgupta N, Nandy P, Sengupta C and Das S. RAPD and ISSR marker mediated genetic polymorphism of two mangroves Bruguiera gymnorrhiza and Heritiera fomes from Indian Sundarbans in relation to their sustainability. Physiol Mol Biol Plants. 2015; 21:375-84. | Article | PubMed Abstract | PubMed FullText

31. Naik A, Prajapat $P$, Krishnamurthy $R$ and Pathak JM. Assessment of genetic diversity in Costus pictus accessions based on RAPD and ISSR markers. 3 Biotech. 2017; 7:70. | Article | PubMed Abstract | PubMed FullText

32. Nei M. Estimation of average heterozygosity and genetic distance from a small number of individuals. Genetics. 1978; 89:583-90. | Article | PubMed Abstract I PubMed FullText

33. Gupta S, Srivastava M, Mishra GP, Naik PK, Chauhan RS, Tiwari SK and Singh R. Analogy of ISSR and RAPD markers for comparative analysis of genetic diversity among different Jatropha curcas genotypes. Afr. J. Biotechnol. 2008; 7. | Article

34. Goulão $L$ and Oliveira $C M$. Molecular characterization of cultivars of apple (Malus domestica Borkh.) using microsatellite (SSR and ISSR) markers. Euphytica. 2001; 122:81-89. | Article

35. Chowdhury MA, Vandenberg B and Warkentin T. Cultivar identification and genetic relationship among selected breeding lines and cultivars in chickpea (Cicer arietinum L.). Euphytica. 2002; 127:317-325. | Article

36. Parsons BJ, Newbury HJ, Jackson MT and Ford-Lloyd BV. Contrasting genetic diversity relationships are revealed in rice (Oryza sativa $L$.) using different marker types. Mol Breeding. 1997; 3:115-125. | Article

37. Zietkiewicz $E$, Rafalski $A$ and Labuda $D$. Genome fingerprinting by simple sequence repeat (SSR)-anchored polymerase chain reaction amplification. Genomics. 1994; 20:176-83. | Article | PubMed

38. Costa R, Pereira G, Garrido I, Tavares-de-Sousa MM and Espinosa F. Comparison of RAPD, ISSR, and AFLP Molecular Markers to Reveal and Classify Orchardgrass (Dactylis glomerata L.) Germplasm Variations. PLoS One. 2016; 11:e0152972. | Article | PubMed Abstract | PubMed FullText

39. Darokar MP, Rai R, Gupta AK, Shasany AK, Rajkumar S, Sundaresan V and Khanuja PS. Molecular assessment of germplasm diversity in Aloe species using RAPD and AFLP analysis. J. Med. Aromat. Plants. 2003; 25:354-361.

40. Shioda H, Satoh K, Nagai F, Okubo T, Seto T, Hamano T, Kamimura H and Kano I. [Identification of Aloe species by random amplified polymorphic DNA (RAPD) analysis]. Shokuhin Eiseigaku Zasshi. 2003; 44:203-7. | Article | PubMed

41. Tripathi N, Saini $\mathrm{N}$ and Tiwari S. Assessment of genetic diversity among Aloe vera accessions using amplified fragment length polymorphism. J. Med. Aromat. Plants. 2011; 1:115-21.

42. Wu FQ, Shen SK, Zhang XJ, Wang YH and Sun WB. Genetic diversity and population structure of an extremely endangered species: the world's largest Rhododendron. AoB Plants. 2014; 7. | Article | PubMed Abstract I PubMed FullText

43. Wabuyele E. A systematic assessment of the relationship between Aloe macrocarpa and Aloe lateritia (Aloaceae). Doctoral dissertation, MSc thesis, Addis Ababa University, Ethiopia. 2000. | Article

44. Jordan JD. The ecology of the Aloe of Zimbabwe. Excelsa. 1996; 17:3544.

45. Panda S, Naik D and Kamble A. Population structure and genetic diversity of perennial medicinal shrubs. Plambago. AoB Plants. 2015; 7:plv048. | Article

46. Williams LK. Gene Mapping. Encyclopedia of Bioinformatics and Computational Biology. 2019.

47. Rosenberg NA, Mahajan S, Ramachandran S, Zhao C, Pritchard JK and Feldman MW. Clines, clusters, and the effect of study design on the inference of human population structure. PLoS Genet. 2005; 1:e70. | Article | PubMed Abstract | PubMed FullText

48. Falush D, Stephens $M$ and Pritchard JK. Inference of population structure using multilocus genotype data: linked loci and correlated allele frequencies. Genetics. 2003; 164:1567-87. | Article | PubMed Abstract | PubMed FullText

49. Patterson N, Price AL and Reich D. Population structure and Eigen analysis. PLoS Genetics. 2006; 2:e190. | Article

50. Jones $\mathrm{N}$, Ougham $\mathrm{H}$ and Thomas $\mathrm{H}$. Markers and mapping: we are all geneticists now. New Phytol. 1997; 137:165-177. | Article

51. Dangasuk OG. Genetic diversity in Faidherbia albida (Del.) A. Chev. Ph.D. Thesis. Moi University, Eldoret, Kenya, 1999.

52. Frankham R, Ballou JD, Eldridge MD, Lacy RC, Ralls K, Dudash MR and Fenster $\mathrm{CB}$. Predicting the probability of outbreeding depression. Conserv Biol. 2011; 25:465-75. | Article | PubMed

53. Lal A, Hales S, French N and Baker MG. Seasonality in human zoonotic enteric diseases: a systematic review. PLoS One. 2012; 7:e31883. | Article | PubMed Abstract | PubMed FullText

54. Powell W, Machray GC and Provan J. Polymorphism revealed by simple sequence repeats. Trends Plant Sci. 1996; 1:215-222. | Article

Citation:

Adienge A, Muturi G, Nadir S, Gicheru J, Kinyua J and Ngaira J. Genetic diversity and population structure of three commercial indigenous Aloe species in selected ASALs of Kenya. J Plant Sci Mol Breed. 2019; 8:1.

http://dx.doi.org/10.7243/2050-2389-8-1 